\title{
Respiratory symptoms and impairment in shipyard welders and caulker/burners
}

\author{
J E COTES, ${ }^{\prime 2}$ E L FEINMANN, ${ }^{1}$ * V J MALE, ${ }^{3}$ F S RENNIE,' C A C WICKHAM ${ }^{4}$ \\ From the Royal Infirmary, Sunderland, ' Division of Environmental and Occupational Medicine, ${ }^{2}$ Medical \\ School, Newcastle upon Tyne NE2 4HH, Northern Regional Health Authority, ${ }^{3}$ Newcastle upon Tyne, and \\ Department of Applied Statistics, ${ }^{4}$ University of Reading, Reading, Berks, UK
}

\begin{abstract}
All 607 men, aged 17 to 69, comprising a stratified sample of workers from one shipyard $\stackrel{\mathbb{1}}{3}$ completed a respiratory questionnaire, clinical examination, and detailed spirometry. Chest radiographs were available on 332 men. Among the men aged 50-69 the prevalence of persistentior cough and phlegm (chronic bronchitis) was $40 \%$, of wheeze on most days $25 \%$, and undue $\mathbb{C}_{0}$ breathlessness on exertion $25 \%$. After allowing for age the relative risk of welders and caulker/ ${ }^{N}$ burners having these symptoms were respectively $2 \cdot 8,2 \cdot 2$, and $3 \cdot 1$ compared with other shipyard tradesmen. The effects were of comparable magnitude to and interacted with those of current $\bar{z}$ smoking. Among the welders and caulker/burners who smoked, the relative risk of developing chronic bronchitis or undue breathlessness was related to the average fume exposure; the relative risk $\vec{\bullet}$ of wheeze was related to the average fume exposure in all smoking categories, with the strongesto association in the ex-smokers. The occurrence of wheeze was also associated with a history of $\sigma$ previous metal fume fever. A history of pleurisy but not of pneumonia was related to the fume exposure in.the welders. After allowing for age and stature, forced expiratory volume $\left(\mathrm{FEV}_{1}\right)$ was on average higher in young welders (age <30) than other tradesmen. In welders and caulker/burners who were current or ex-smokers, FEV $_{1}$ and PEF were reduced in relation to the average fume $\frac{\odot}{\varnothing}$ exposure (mean reductions respectively 0.251 and $0.991 \mathrm{~s}^{-1}$ ). The $\mathrm{FEV}_{1} \%$ (of forced vital capacity), $\stackrel{\overrightarrow{\vec{P}}}{\overrightarrow{2}}$ the flow rates at small lung volumes $\left(\mathrm{MEF}_{50 \% \mathrm{Fvc}}\right.$ and $\left.\mathrm{MEF}_{25 \% \mathrm{Fvc}}\right)$, the mean transit time, and its 3 standard deviation were also reduced by fume exposure or the declines with age were increased, or $\vec{F}$ both. No impairment was demonstrable in the non-smokers and many men had given up smoking: with apparently beneficial results. The occupational component of the respiratory impairment related mainly to exposures in the past; information was needed on the effects of present conditions in the $\frac{\mathbb{N}}{3}$ industry.
\end{abstract}

In NE England ships are made from mild steel. The sheets are joined by welders who normally use flux covered electrodes (manual metal arc welding). Burners, whose trade is linked to that of caulkers, buff and burn off any metal protruding from the completed welds; they also gouge and cut the welded plates. Both groups of tradesmen are exposed to fumes from the weld metal (iron with an admixture of other substances), flux, coating materials, and solvents; the men may also inhale carbon monoxide, nitrogen dioxide,

*Dr Feinmann died on 25 July 1983.

Present address: CACW: MRC Environmental Epidemiology Unit, University of Southampton, Southampton, Hants.

Accepted 23 May 1988 ozone, and cigarette smoke. Asbestos from lagging was formerly an additional hazard but this is now? mainly a problem of ship repairing and breaking $\frac{D}{0}$ Respiratory protection is by local exhaust ventilation or air supplied respirators; these measures are of recent origin and not universally applied.

Compared with other shipyard tradesmen the welders have a raised standardised mortality ratio from $\omega$ pneumonia, and the caulker/burners from pneumonia and chronic bronchitis.' The forced expiratory volume has been reported as either normal ${ }^{2}$ or reduced by welding fumes in association with smoking. ${ }^{34}$ The $^{-}$ evidence up to 1979 has been reviewed by Newhouse $\frac{0}{0}$ and Murray. ${ }^{5}$ Recent studies have suggested that at least some of the respiratory morbidity and mortality among welders is due to asbestos ${ }^{6}$ whereas, except in尺 
the case of stainless steel, ${ }^{7}$ the role of welding fumes is believed to be relatively unimportant. ${ }^{8}$ In one study where the opposite conclusion was reached the control group was inappropriate. ${ }^{9}$ Among ship maintenance and repair workers at Devonport dockyard, welders had prolonged sickness absences from respiratory infections. ${ }^{10}$ Compared with these men the welders who build ships may experience higher concentrations of fumes from working in the double bottom of ships and other confined spaces. Among such men the forced expiratory volume and transfer factor of nonsmoking welders have been reported as reduced " but sampling was not systematic and the controls were office staff not tradesmen. The present study at the same shipyard assesses the situation in greater detail.

\section{Subjects and methods}

The shipyard population was defined as all men on the payroll at 31 December 1978 plus the 37 welders who had left during the preceding nine years. Of the latter, 14 were dead, 10 had retired, and 13 had left for other reasons. A sample was drawn comprising all men aged 45 or over whose current or last occupation was as a welder or caulker/burner, $50 \%$ of welders and caulker/ burners aged less than 45 , all the tack welders, and $5 \%$ of other tradesmen, including riveters, fitters, electricians, and carpenters. Sampling was by random selection. Subsequently all foreman welders and plumber welders ( 20 of each) and two plater operators of fairing equipment were added to the survey population. After the survey the men who had ever been a welder, or failing that, a caulker/burner, were included under one of these headings (table 1). Information was incomplete (usually from omissions during a domiciliary visit) in approximately $5 \%$ of men; a similar proportion refused to participate. Subjects completed an employment questionnaire, then were seen by one of four physicians (ELF, VJM, JHRR,

Table 1 Study population analysed by trade

\begin{tabular}{|c|c|c|c|c|}
\hline & No in sample & & & $\begin{array}{l}\text { No with } \\
\text { complete } \\
\text { data* }\end{array}$ \\
\hline $\begin{array}{l}\text { Age range (y) } \\
\text { Welders: }\end{array}$ & $17-44$ & $45-70$ & $17-70$ & $17-70$ \\
\hline $\begin{array}{l}\text { Current } \\
\text { Ex-employees } \\
\text { Foremen } \\
\text { Plumbers }\end{array}$ & $\begin{array}{ll}105 & \\
- & 20 \\
& 20\end{array}$ & $\left.\begin{array}{r}179 \\
37\end{array}\right\}$ & 361 & 353 \\
\hline $\begin{array}{l}\text { Caulker/burners } \\
\text { Tack welders } \\
\text { Other tradesmen }\end{array}$ & $\begin{array}{l}44 \\
21\end{array}$ & $\begin{array}{l}70 \\
85\end{array}$ & $\begin{array}{l}114 \\
106 \\
105\end{array}$ & $\begin{array}{r}117 \\
56 \\
81\end{array}$ \\
\hline Total & & & 686 & $607 \dagger$ \\
\hline
\end{tabular}

*After reclassifying as welders or caulker/burners men who subsequently moved to other trades.

tof 79 lapses, 14 were dead, 34 had refused, and 31 had incomplete data.
FSR). They filled in a detailed questionnaire based on the MRC questionnaire on respiratory symptoms and McMillan's dockyard survey questionnaire ${ }^{10}$; questions were asked on anginal symptoms. The men underwent a clinical examination.

Stature was measured with a Harpenden stadiometer, body mass with a calibrated beam balance, and skinfold thickness at four sites with Holtain skin calipers; the measurements were used to estimate fat free mass and percentage body fat. ${ }^{12}$ Trunk dimensions were also obtained but did not contribute usefully to the analysis.

The forced expiratory volume $\left(\mathrm{FEV}_{1}\right)$ and vital capacity (FVC) were obtained by one of two experienced observers each using a McDermott bellows spirometer with digital display and incremental volume output (10 ms increments, $\left.{ }^{13}\right)$; the spirometers were calibrated four times daily. The subjects made two practice expirations, then three technically satisfactory results were obtained, and the highest value for each index was analysed. Spirometric results obtained on 27 men during domiciliary visits by other observers were not included in the analysis (see results). Flow volume curves were displayed on a JJ XY recorder and inspected at the time for shape and consistency. The information was recorded on a Sony 2 channel tape recorder. Tapes were analysed using a Hewlett Packard 9825 computer and printer. Peak expiratory flow rate was the mean over $30 \mathrm{~ms}$ (PEFR); other flow rates were taken at the point when $50 \%$ and $25 \%$ of FVC remained to be expired $\left(\mathrm{MEF}_{50 \% \mathrm{Fvc}}\right.$ and $\mathrm{MEF}_{25 \% \mathrm{Fvc}}$ respectively). Transit time indices were the mean (MTT) and the standard deviation (SDTT). Expiration was considered to have started after expiration of $100 \mathrm{ml}$ and to have ended when the volume expired in $0.5 \mathrm{~s}$ did not exceed $25 \mathrm{ml}$ or, for the transit times, when the expiration had continued for $6 \mathrm{~s}$. The two curves having the highest FVC were analysed; for the flow indices the higher of the two results was used, provided that the curves were of acceptable shape (see results), the FVCs agreed to within $5 \%$, and the peak flow rates to within $10 \%$. When this criterion was not met the result was taken from the expiration with the higher FVC. The transit time indices were taken from the expiration with the shorter mean transit time of the two which were analysed..$^{14}$

Chest radiographs were available for 332 men; most were taken during a radiographic survey in 1977 and the remainder at the time of the study - that is, two years later. Three independent observers read each film for round and irregular small opacities and other abnormalities using the ILO International Classification of Pneumoconioses. ${ }^{15}$ Majority readings were subsequently extracted by the authors and the profusion scores $0 /$ - and $0 / 0$ were amalgamated. 
A year after the survey, a subsample comprising the men with wheeze on most days, breathlessness grade 3 or above, or impaired lung function were reassessed, together with a sample of other men. The results obtained were used to check the stability of those of the main survey. The survey results after checking were transferred to an ICL 2966 computer running under the George 3 operating system. A preliminary descriptive analysis was undertaken and for each man indices of exposure to fumes as a welder or caulker/ burner and reference values for $\mathrm{FEV}_{1}$ were calculated..$^{12}$ The exposure indices for welders were W1 ever a welder, W2 years welding, W3 total fume exposure; this was the sum of the duration of each period of work as a welder multiplied by the proportion of time spent in confined spaces $(<25 \%$ of time, $25-75 \%,>75 \%$ of time), W4 discounted fume exposure was as for $\mathrm{W} 3$ but with additional weighting given to exposure in the distant past, W5 accumulated fume exposure was as for $\mathrm{W} 3$ but additional weighting given to recent exposure. ${ }^{16}$ Average exposure (AE) was total fume exposure (W3) divided by duration of exposure. Similar indices were calculated for caulker/ burners (C/B 1-5) and tack welders. Ever a welder or caulker/burner provided an overall index of fume exposure.

Results were entered into a multivariate analysis as either continuous or dummy variables (present or absent). The latter included exposure indices W1 and C/B1, smoking or ex-smoking, previous pneumonia or pleurisy, asbestos exposure, and cough with phlegm for more than three months in the year; the latter symptoms were evidence for simple chronic bronchitis (MRC, ${ }^{17}$ ). Wheeze was scored on the 3 point scale, (3) absent, (2) present occasionally, or (1) present on most days or nights. Breathlessness was analysed using an extended scale based on the clinical grades of Fletcher. ${ }^{1218}$ Multiple regression and logistic regression analyses were performed using an IBM 370 computer, the computer package GLIM (Numerical Algorithms Group, Oxford), the Statistical Package for the Social Sciences (SPSS) of the University of Michigan, ${ }^{19}$ and BMDP statistical software. ${ }^{20}$ The dependent variables in the regression analyses were the lung function indices, the category of pneumoconiosis, and the respiratory symptoms. The independent variables were stature, mass/stature ${ }^{2}$, age, smoking, exsmoking, previous chest illnesses, and exposure to asbestos; the effects of exposure to fumes from welding or burning were assessed in terms of average exposure for welders and caulker/burners alone, and of trade as a welder or caulker/burner when comparison was made with men in other trades. Tack welders were excluded from the latter comparisons. For analyses including interaction terms the variables, age and average exposure, were centred about their mean values.
Multiple regression analysis was performed using a $\bar{z}$ forward stepwise method, the independent variable $\stackrel{\odot}{\circ}$ giving the largest reduction in the residual sum of squares being selected first. The exception was the $\stackrel{?}{+}$ exposure variable which was fitted after the other $\bar{c}$ important variables had been included in the model. $\frac{\bar{\sigma}}{\bar{F}}$ The analysis was carried out both without and with $\frac{\bar{c}}{\frac{\sigma}{2}}$ allowance for possible interaction between age, smok- $\stackrel{\mathbb{}}{\varrho}$ ing, and exposure. The regression coefficients were $⿻$ considered to be significant at the $5 \%$ level of probability. The results of the logistic regression were $\vec{\circ}$ reported in terms of the relative risk compared with $\overrightarrow{\vec{\omega}}$ unity which implied no contribution from the variable $\stackrel{\sigma}{\sigma}$ in question.

\section{Results}

\section{DESCRIPTION OF SUBJECTS}

The welders or caulker/burners in the survey popula- $N$ tion had a wide range of exposure to fumes. The exposure indices $\mathrm{W} 2$ through to $\mathrm{W} 4$ and $\mathrm{CB} 2$ to $\mathrm{CB} 4-$ were highly correlated with age; the indices W5 and CB5 were weakly correlated, whereas the average exposure (AE) was independent of age. Accordingly $\vec{\oplus}$ this latter index was used in the analysis; the mean 0 values and standard deviations for welders and $\square$ caulker/burners respectively were $1.93(0.60)$ and 1.87 을 $(0.54)$ units. The interaction term, AE $\times$ age (based on centred variables), was independent of age and only weakly correlated with $\mathrm{AE}(r=0.095)$ so all three $\frac{\circ}{\Phi}$ terms could be included together in the multiple $\stackrel{\circ}{\Rightarrow}$ regression analyses. Among the survey population $\vec{O}$ there were no former coalworkers or quarry men. 3 Exposure to asbestos occurred from working alongside laggers (399 men), using asbestos cloth (79 men), working as a limpet sprayer (53 men), or working as a lagger ( $35 \mathrm{men})$. Of the welders and tack welders, $71 \%$ had experienced ray burns or arc eye; $35 \%$ of the $\frac{5}{3}$ welders and $29 \%$ of the caulker/burners had had metal fume fever associated with exposure to zinc. Fifty six per cent of participants were current cigarette smok-

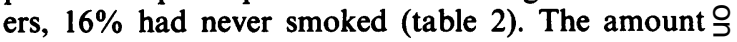
currently smoked was independent of age and trade $>$ (mean value $21.7 \mathrm{~g} /$ day, range $1-70 \mathrm{~g}$ ). The proportion of ex-smokers among the survey population (table 3) N and among the welders but not the caulker/burners separately was significantly higher than expected for 0 men in this social class in the United Kingdom. Of the $\underset{\omega}{N}$ men for whom there were chest radiographs, $22(6.6 \%)$ 을 had simple pneumoconiosis grade $2 / 1$ or above. Ao history of pleurisy or pneumonia or chest injury or $\bar{\varnothing}$ haemoptysis was given by $8-16 \%$ of men. Four per $\stackrel{\mathscr{?}}{+}$ cent experienced exercise related discomfort sugges- $\square$ tive of angina; 12 of these men (out of 23) were $\stackrel{\vec{D}}{\vec{D}}$ subsequently studied in detail and notable ischaemic $\stackrel{\Phi}{\odot}$ heart disease was present in one. Three per cent of the $\stackrel{\mathbb{D}}{\varrho}$ men had had tuberculosis and $25 \%$ had kept pigeons 
Table 2 Percentage of respiratory symptoms and smoking habits by age group*

\begin{tabular}{|c|c|c|c|c|c|}
\hline $\begin{array}{l}\text { Age group }(y) \\
\text { No }\end{array}$ & $\begin{array}{l}20-29 \\
64\end{array}$ & $\begin{array}{l}30-39 \\
86\end{array}$ & $\begin{array}{l}40-49 \\
160\end{array}$ & $\begin{array}{l}50-59 \\
262\end{array}$ & $\begin{array}{l}60-69 \\
26\end{array}$ \\
\hline $\begin{array}{l}\text { Cough and phlegm } \\
>3 / 12 \\
\text { Wheeze. }\end{array}$ & 21.9 & 20.9 & 32.5 & 37.8 & $50.0+$ \\
\hline $\begin{array}{l}\text { Wheeze: } \\
\text { (i) } \\
\text { (ii) } \\
\text { Total }\end{array}$ & $\begin{array}{r}26.6 \\
7.8 \\
34.4\end{array}$ & $\begin{array}{l}36.0 \\
16 \cdot 3 \\
52 \cdot 3\end{array}$ & $\begin{array}{l}39 \cdot 4 \\
16.9 \\
56 \cdot 3\end{array}$ & $\begin{array}{l}41 \cdot 2 \\
26 \cdot 3 \\
67 \cdot 5\end{array}$ & $\begin{array}{l}30.8 \\
26.9 \dagger \\
57.7\end{array}$ \\
\hline $\begin{array}{l}\text { Breathlessness: } \\
\text { Grade 3 } \\
\text { Grade 4-5 } \\
\text { Total }\end{array}$ & $\begin{array}{l}1.6 \\
0 \\
1.6\end{array}$ & $\begin{array}{l}7 \cdot 0 \\
1 \cdot 1 \\
8 \cdot 1\end{array}$ & $\begin{array}{r}13.8 \\
0.6 \\
14.4\end{array}$ & $\begin{array}{r}21 \cdot 4 \\
4.2 \\
25.6\end{array}$ & $\begin{array}{l}19 \cdot 2 \dagger \\
19 \cdot 2 \dagger \\
38.4\end{array}$ \\
\hline $\begin{array}{l}\text { Smokers: } \\
\text { Cigarettes } \\
\text { Other } \\
\text { Total } \\
\text { Ex-smokers } \\
\text { Never smoked }\end{array}$ & $\begin{array}{r}57 \cdot 8 \\
3 \cdot 1 \\
60 \cdot 9 \\
17 \cdot 2 \\
21 \cdot 9\end{array}$ & $\begin{array}{r}46 \cdot 6 \\
2 \cdot 3 \\
48 \cdot 9 \\
24 \cdot 4 \\
26 \cdot 7\end{array}$ & $\begin{array}{r}53 \cdot 1 \\
1 \cdot 3 \\
54 \cdot 4 \\
25 \cdot 6 \\
20 \cdot 0\end{array}$ & $\begin{array}{r}60 \cdot 1 \\
2 \cdot 1 \\
62 \cdot 2 \\
29 \cdot 0 \\
8 \cdot 8\end{array}$ & $\begin{array}{r}61 \cdot 5 \\
3.9 \\
65 \cdot 4 \\
26.9 \\
7.7\end{array}$ \\
\hline
\end{tabular}

*Nine men aged $<20$ are omitted from this table.

tSignificant relation to age ( $p<0.05)$; a more complete analysis is given in the text.

or budgerigars, but none had evidence of bird fanciers' lung. Chronic bronchitis (MRC) was recorded by 33\% of men, $21 \%$ recorded wheeze on most days or nights, $18 \%$ admitted to breathlessness grade 3 or more, and $11 \%$ had a reduced $\mathrm{FEV}_{1}(<2 \mathrm{SD})$. The prevalence of these abnormalities was related to age (table 2 and fig 1). Mean results for some anthropometric and lung function measurements are given in table 4.

\section{RESPIRATOR Y SYMPTOMS}

The principal determinant of chronic bronchitis was smoking which, after allowing for age and trade, was associated with a threefold increased risk compared with non-smokers and ex-smokers (relative risk $3 \cdot 2$, $95 \%$ confidence limits $2 \cdot 1-4 \cdot 6)$. The risk of chronic bronchitis increased with age and with physique, the short heavy subjects being more at risk than subjects with a low value for mass $/ \mathrm{st}^{2}$. After allowing for age and current smoking, work as a welder or caulker/ burner was associated with an increased risk of

Table 3 Numbers of men in different smoking categories by age groups compared with United Kingdom averages for social class III manual workers (Tobacco Advisory Council, 1980)

\begin{tabular}{llll}
\hline & Age $(y)$ & & \\
\cline { 2 - 4 } & $25-34$ & $35-49$ & $50-64$ \\
\hline $\begin{array}{c}\text { Current smokers: (any product) } \\
\begin{array}{c}\text { Observed } \\
\text { Expected }\end{array}\end{array}$ & 40 & 117 & 177 \\
$\begin{array}{c}\text { Ex-smokers* } \\
\text { Observed } \\
\text { Expected }\end{array}$ & 44.0 & 123.4 & 189.7 \\
$\begin{array}{c}\text { Non-smokers } \\
\text { Observed } \\
\text { Expected }\end{array}$ & 16 & 56 & 82 \\
\hline
\end{tabular}

${ }^{*}$ Excess of ex-smokers was significant $\left(\chi_{4}^{2}=21 \cdot 52, p<0.001\right)$. chronic bronchitis compared with other trades (relative risk 2.8 (1.4-5.5)). In addition there was significant interaction between the effects of smoking and of welding fumes. Among welders and caulker/ burners who smoked, the increased risk of chronic bronchitis was related to the average fume exposure. For the combined non-smokers and ex-smokers, the risk associated with the welding trades was also increased, but the increase was not relative to the average exposure and there was no association with trade when ex-smokers and non-smokers were examined separately (table 5 and fig 2 ). The nonsmoking other tradesmen, however, comprised only 19 men. Previous pneumonia or pleurisy were significant antecedents of chronic bronchitis. The occurrence of pneumonia was related to age but was independent of the other variables, including fume exposure. Pleurisy was related to age in the welders; for the whole shipyard population it was also related to smoking, stature, and systolic blood pressure. In welders, after allowing for age, the prevalence of pleurisy was related to the average exposure.

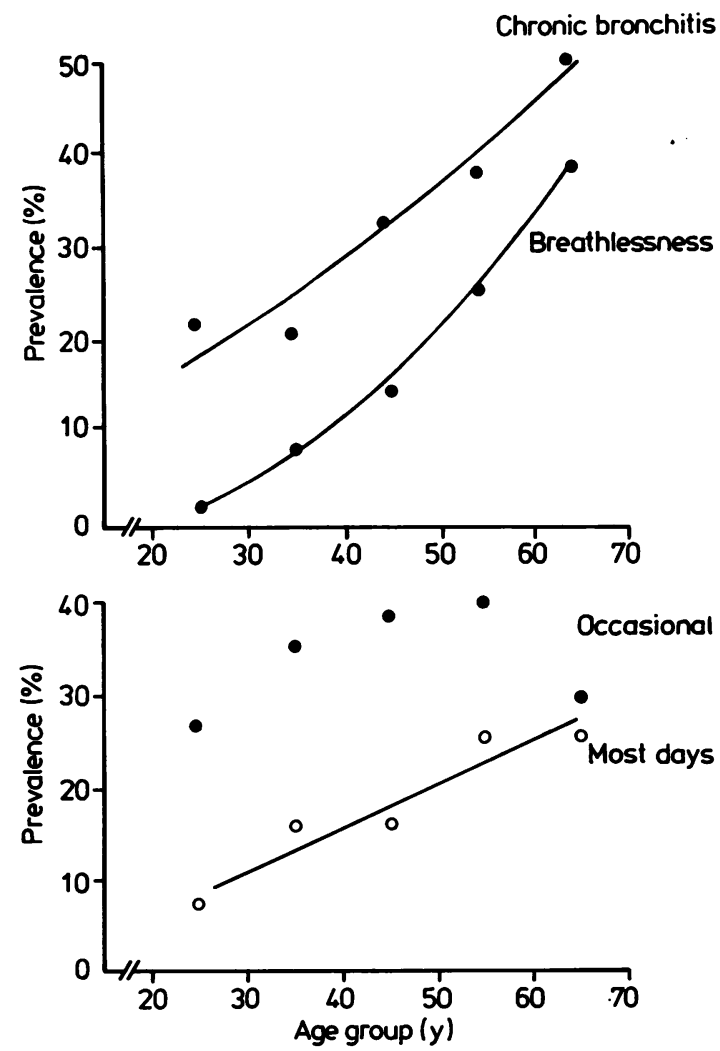

Fig 1 Prevalences of chronic bronchitis, breathlessness grade 3 or above, and wheeze occasionally or on most days in relation to age. 
Table 4 Mean values and SD for lung function and related indices in the shipyard population. Mean values for the welders and caulker/burners whose results were included in the analysis summarised in table 8 are given in parentheses ( $n$ $=360-371$ for the different indices)

\begin{tabular}{|c|c|c|c|c|c|}
\hline & & $n$ & Mean & & $S D$ \\
\hline $\begin{array}{l}\text { Age } \\
\text { Body mass } \\
\text { Stature } \\
\text { Body mass/st }^{2} \\
\text { Forced expiratory volume } \\
\text { Forced vital capacity } \\
\text { FEV } / \text { FVC } \\
\text { Peak expiratory flow } \\
\text { Maximal expiratory flow: } \\
\text { MEF } \\
\text { ME\%Fvc } \\
\text { MeF }{ }_{25 \% F y c} \\
\text { Mean transit time } \\
\text { SDTT }\end{array}$ & $\begin{array}{l}\text { (a) } \\
(\mathrm{kg}) \\
(\mathrm{m}) \\
\left(\mathbf{k g ~ m ^ { - 2 }}\right) \\
(1) \\
(1) \\
(\%) \\
\left(1 \mathrm{~s}^{-1}\right) \\
\left(1 \mathrm{~s}^{-1}\right)\end{array}$ & $\begin{array}{l}575 \\
568 \\
574 \\
568 \\
575 \\
575 \\
575 \\
575 \\
\\
572 \\
573 \\
553 \\
553\end{array}$ & $\begin{array}{l}46 \cdot 0 \\
75 \cdot 7 \\
1 \cdot 71 \\
25 \cdot 7 \\
3 \cdot 10 \\
4 \cdot 36 \\
70 \cdot 6 \\
8 \cdot 88 \\
3 \cdot 62 \\
1 \cdot 16 \\
0 \cdot 785 \\
0 \cdot 98\end{array}$ & $\begin{array}{l}(47 \cdot 0) \\
(75 \cdot 6) \\
(1 \cdot 72) \\
(25 \cdot 6) \\
(3 \cdot 05) \\
(4 \cdot 33) \\
(70 \cdot 0) \\
(8 \cdot 88) \\
(3 \cdot 56) \\
(1 \cdot 10) \\
(0 \cdot 800) \\
(1 \cdot 00)\end{array}$ & $\begin{array}{c}10.8 \\
11.7 \\
0.07 \\
3.5 \\
0.84 \\
0.90 \\
10.3 \\
2.46\end{array}$ \\
\hline
\end{tabular}

The occurrence of wheeze occasionally and wheeze on most days or nights were initially analysed separately but with similar results; the two were combined for the following account. Wheeze was related to age, current smoking, systolic blood pressure, chronic bronchitis, and previous metal fume fever. From logistic regression analysis of wheeze on age, current smoking, and trade, the relative risk for current smokers compared with non-smokers and exsmokers was $2.7(1.9-3.9)$, and the relative risk associated with the trade of welder or caulker/burner was $2 \cdot 2(1 \cdot 3-3 \cdot 7)$. In addition, for all smoking categories of welders and caulker/burners there was a significant dependency of wheeze on average fume exposure. There was also significant interaction between smoking and trade. Considering individual smoking categories the relation with fume exposure was strongest in the case of caulker/burners who were ex-smokers (table 6); it was no longer significant when allowance was made for co-existing chronic bronchitis. Among welders and caulker/burners, after

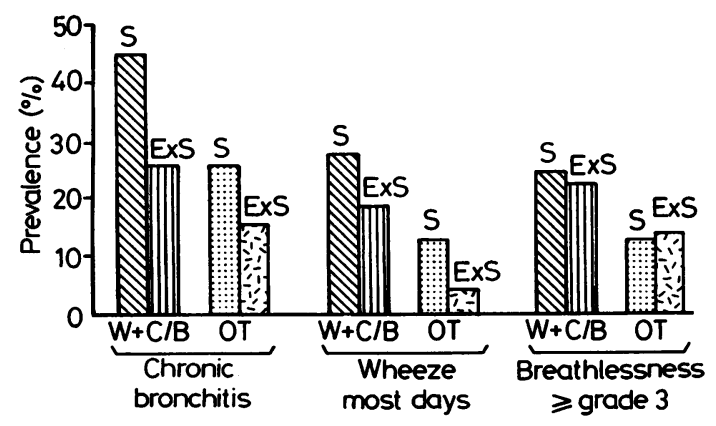

Fig 2 Prevalences of respiratory symptoms in men who had ever smoked, subdivided by trade (welders and caulker) burners $(W+C / B)$ or other tradesmen $(O T))$ and by smoking category (smokers (S) or ex-smokers (ExS)).
Table 5 Relative risk of chronic bronchitis in welders $(W)$ or caulker/burners $(C / B)$ compared with other tradesmen (OT). Allowance made for age

\begin{tabular}{|c|c|c|c|}
\hline \multirow[b]{3}{*}{$\begin{array}{l}W>O T \\
C B>O T\end{array}$} & \multicolumn{3}{|c|}{ Relative risk with $95 \%$ confidence interval } \\
\hline & \multirow{2}{*}{$\begin{array}{l}\text { Smokers } \\
2 \cdot 1(1 \cdot 0-4 \cdot 4) \\
2 \cdot 7(1 \cdot 2-6 \cdot 0)\end{array}$} & \multicolumn{2}{|c|}{ Ex-smokers Non-smokers } \\
\hline & & $\begin{array}{l}\text { TNS } \\
\text { TNS }\end{array}$ & $\begin{array}{l}\text { TNS } \\
\text { TNS }\end{array}$ \\
\hline $\mathrm{W}$ or $\mathrm{C} / \mathrm{B}>\mathrm{OT}^{*}$ & $2 \cdot 3(1 \cdot 1-4.8) \dagger$ & \multicolumn{2}{|c|}{$3.4(1 \cdot 1-10 \cdot 6)$} \\
\hline
\end{tabular}

TNS $=$ Term not significant.

*For all subjects allowing for age and current smoking $2.8(1.4-5.5)$. †Significant association with average fume exposure in welders and $\vec{\omega}$ caulker/burners, independent of metal fume fever.

allowing for age, smoking, and average exposure, a $\vec{\oplus}$ history of metal fume fever carried an increased risk of $i$ wheeze (relative risk in smokers and non-smokers as a î group, $2 \cdot 3,1 \cdot 4-3 \cdot 8)$.

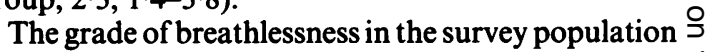
was associated positively with chronic bronchitis, age, $\vec{z}$ mass/stature ${ }^{2}$, current or ex-smoking, pleurisy, exertional chest discomfort, and wheeze; it was negatively associated with stature. After allowing for age, stature, $\vec{\oplus}$ mass/stature ${ }^{2}$, and chronic bronchitis, the risk of $\oplus$ breathlessness grade 3 or above was increased in welders and caulker/burners compared with other tradesmen. The risk was not independent of smoking category; among current smokers the relative risk was $3 \cdot 2(1 \cdot 1-9 \cdot 9)$ but there was no detectable increased risk $\Phi$ for non-smokers or ex-smokers, either separately or in $\underset{\overrightarrow{7}}{\overrightarrow{7}}$ combination (table 7). For the welders and caulker/ burners who smoked the increased risk of breathlessness was related to the average fume exposure. The breathlessness was associated with chest discomfort during exercise.

\section{RAY CATEGORY OF SIMPLE PNEUMOCONIOSIS}

(SMALL OPACITIES)

The 332 men on whom chest radiographs were $ᄋ$ available were predominantly welders $(63 \%)$, caulker/

Table 6 Relative risk of wheeze in welders $(W)$ or caulker/ burners $(C / B)$ compared with other tradesmen $(O T)$.

Allowance made for age

\begin{tabular}{|c|c|c|c|}
\hline & \multicolumn{3}{|c|}{ Relative risk with $95 \%$ confidence interval } \\
\hline & Smokers & Non-smokers & Ex-smokers \\
\hline $\begin{array}{l}\mathrm{W}>\mathrm{OT} \\
\mathrm{CB}>\mathrm{OT} \\
\mathrm{W} \text { or } \mathrm{C} / \mathrm{B}>\mathrm{OT}^{*}\end{array}$ & $\begin{array}{l}1 \cdot 8(0 \cdot 9-3 \cdot 7) \\
\text { TNS } \\
\text { TNS }\end{array}$ & $\begin{array}{l}3.2(0.7-12.8) \\
\text { TNS } \\
2 \cdot 7(0.8-9.4) \\
\end{array}$ & $\begin{array}{l}2 \cdot 9(0 \cdot 8-10 \cdot 0) \\
4 \cdot 4(1 \cdot 1-17 \cdot 6) \\
3 \cdot 1(1 \cdot 2-7 \cdot 8) \dagger\end{array}$ \\
\hline
\end{tabular}

TNS $=$ Term not significant .

* For all subjects allowing for age and current smoking 2.2 (1-3-3.7). Previous metal fume fever also contributed significantly.

tSignificant association with average fume exposure in welders and $\frac{\rho}{(1)}$ caulker/burners, independent of metal fume fever. 
Table 7 Relative risk of breathlessness grade 3 or above in welders $(W)$ or caulker/burners $(C / B)$ compared with other tradesmen $(O T)$. Allowance made for age

\begin{tabular}{llll}
\hline & \multicolumn{3}{l}{ Relative risk with 95\% confidence interval } \\
\cline { 2 - 4 } & Smokers & \multicolumn{2}{l}{ Ex-smokers Non-smokers } \\
\hline W $>$ OT & $2 \cdot 9(1 \cdot 0-9 \cdot 8)$ & TNS & TNS \\
CB $>$ OT & $5.6(1 \cdot 4-21 \cdot 2)$ & $\underbrace{\text { TNS }}_{\text {TNS }}$ & TNS \\
W or C/B $>$ OT $^{*}$ & $3 \cdot 2(1 \cdot 1-9 \cdot 9) \dagger$ & \multicolumn{2}{l}{ TNS } \\
\hline
\end{tabular}

TNS $=$ Term not significant.

*For all subjects allowing for age 3.1 (1·3-7.7)

†Significant association with average fume exposure in welders and caulker/burners, independent of metal fume fever.

burners $(19 \%)$, and tack welders $(5 \%)$. They were on average similar to the remainder in respect of age, fume exposure, $\mathrm{FEV}_{1}$, and all the attributes given in table 2. Before statistical analysis the results for 13 men whose chest radiographs showed notable abnormalities other than pneumoconiosis were excluded and 12 data sets were excluded on account of one or more missing items. Among the remaining 307 men were 20 in whom the profusion of small opacities was $2 / 1$ or above; in 13 the opacities were round, in six predominantly round, and in one predominantly irregular. Among the exclusions were two with category $2 / 1$ or above; in both the opacities were round. The profusion of small opacities was related to age and exposure to welding fumes; together these variables accounted for $18 \%$ of the variance. There were no associations with smoking, respiratory symptoms, or impaired lung function.

\section{LUNG FUNCTION}

Complete results were obtained on nearly all subjects other than the 27 men who were seen at home; on these men, flow volume curves were not recorded. In addition, in many instances the FEV, or FVC was materially lower than at the 12 month follow up. Accordingly, the results for men seen at home were not included in the analysis. Also excluded were the flow volume results for 22 men with atypical curves; the latter exclusions did not influence the findings. The $\mathrm{FEV}_{1}$ was related positively to stature and negatively to age, current or ex-smoking, systolic blood pressure, chronic bronchitis, wheeze, previous pleurisy, and previous pneumonia. Fume exposure was also related to some of these variables (see above) so when examining its possible association with impaired lung function allowance was made only for the independent variables age, stature, and smoking. The analysis was confined to the welders and caulker/burners as in these men the lung function could be related to the average fume exposure; significant associations were observed in the smokers and ex-smokers as separate groups but not in the non-smokers. Among welders and caulker/ burners who were smokers or ex-smokers the average fume exposure contributed to the description of all the indices obtained by dynamic spirometry except FVC; either or both the absolute level was reduced and the decline with age was increased. When the whole analysis was repeated including the non-smokers, a similar result was obtained (table 8). For most of the indices of lung function the ex-smokers had significantly better lung function than the smokers. The adverse effect of smoking, however, was not related to the number of cigarettes currently smoked a day. Among the smokers the results did not differ as between the welders and caulker/burners. By contrast, among the non-smokers and ex-smokers, after allowing for age and stature, the welders had higher values for peak expiratory flow rate $\left(\triangle P E F 0.961 \mathrm{~s}^{-1}\right)$ and forced expiratory volume $\left(\triangle F E V_{1} 0.231\right)$ than the caulker/burners. In addition, among the shipyard workers aged less than 30 , the $\mathrm{FEV}_{1}$ was $9 \%$ higher among the welders than the other tradesmen, despite the two groups having similar age, stature, and tobacco consumption.

\section{Discussion}

This study describes the respiratory health of current shipyard workers and surviving welders or caulker/ burners from among those who had left within the

Table 8 Multiple regression equations describing indices of airflow limitation in welders and caulker/burners who had ever smoked. Age and AE were centred about their mean values (table 4): (For abbreviations, see methods)

\begin{tabular}{|c|c|c|c|c|c|c|c|c|}
\hline Regression coefficient & $\begin{array}{l}F E V_{1} \\
(l)\end{array}$ & $\begin{array}{l}F V C \\
(l)\end{array}$ & $\begin{array}{l}F E V \% * \\
(\%)\end{array}$ & $\begin{array}{l}P E F^{*} \\
\left(l, s^{1}\right)\end{array}$ & $\begin{array}{l}M E F_{\text {so\%rvc }} \\
\left(l, s^{\prime}\right)^{*}\end{array}$ & $\begin{array}{l}M E F_{25 \% \mathrm{Fvc}} \\
\left(l, s^{1}\right)^{*}\end{array}$ & $\begin{array}{l}M T T^{*} \\
\left(s \times 10^{-3}\right)\end{array}$ & $\begin{array}{l}S D T T^{*} \\
\left(s \times 10^{-3}\right)\end{array}$ \\
\hline $\begin{array}{l}\text { Age }\left(y \times 10^{-3}\right) \\
\text { Stature }(\mathrm{m}) \\
\text { Average exposure }(\mathrm{AE}) \\
\text { AE } \times \text { age }\left(\times 10^{3}\right) \\
\text { If ex-smoker } \\
\text { Constant } \\
\text { SEE } \\
\mathbf{R}^{2}(\%)\end{array}$ & $\begin{array}{l}-36 \\
5 \cdot 03 \\
-0 \cdot 13 \\
- \\
- \\
-3 \cdot 40 \\
0.58 \\
49 \cdot 6\end{array}$ & $\begin{array}{l}-34 \\
7 \cdot 70 \\
- \\
- \\
-7 \cdot 28 \\
0 \cdot 62 \\
53 \cdot 8\end{array}$ & $\begin{array}{l}-415 \\
-15 \cdot 2 \\
-3 \cdot 28 \\
-304 \\
2 \cdot 94 \\
95 \cdot 2 \\
9 \cdot 37 \\
18 \cdot 2\end{array}$ & $\begin{array}{l}-76 \\
8 \cdot 13 \\
-0 \cdot 52 \\
- \\
0 \cdot 57 \\
-1 \cdot 73 \\
1 \cdot 83 \\
26 \cdot 3\end{array}$ & $\begin{array}{l}-63 \\
4 \cdot 21 \\
- \\
-31 \dagger \\
0.45 \\
-0.86 \\
1 \cdot 39 \\
23.0\end{array}$ & $\begin{array}{l}-36 \\
1 \cdot 41 \\
- \\
-10 \dagger \\
0.18 \\
0 \cdot 26 \\
0.50 \\
36 \cdot 4\end{array}$ & $\begin{array}{l}7 \cdot 2 \\
430 \\
66 \\
5 \cdot 6 \\
-52 \\
76 \cdot 2 \\
200 \\
13 \cdot 2\end{array}$ & $\begin{array}{l}8.9 \\
- \\
4.7 \dagger \\
-52 \\
1019 \\
236 \\
11.6\end{array}$ \\
\hline
\end{tabular}

*Exposure terms also significant with non-smokers included in the equation (smoking scored 0, 1, 2 for non, ex-, and current smokers). †Term significant in presence of AE which was not itself significant. 
preceding nine years. It throws no comparable light on the men who died during the nine years or those who left before that. In addition, no information was obtained on the $5 \%$ of men who refused to participate; however, their omission was unlikely to have materially influenced the result. The exclusion from the analysis of lung function of results obtained at domiciliary visits led to the omission of some subjects with material respiratory impairment, but this was necessary if only reliable information was to be analysed. The exclusion of current tack welders from comparisons between men who had ever been welders or caulker/burners and men in other trades was also necessary on account of the fume exposure of tack welders being intermediate between those of the main groups. The effects of their exclusion were mainly quantitative rather than qualitative.

\section{QUALITY OF INFORMATION INCLUDED IN THE ANALYSIS}

The occupational histories were checked by occupational nurses in the shipyards and again by the chest physicians at clinical interview. Comparison with information obtained subsequently on a subsample of men showed that estimates of time spent welding or caulker/burning in confined spaces $(<25 \%, 25-75 \%,>75 \%)$ were rather variable but otherwise the occupational histories were consistent. This was also the case for the answers to respiratory questions in men whose circumstances had not changed in other respects-for instance, smoking habit or medical treatment. The anthropometric measurements were made using standard procedures; some variation may have occurred in the measurements of skinfold thickness and chest wall and sternal lengths but these indices did not contribute usefully to the results. The spirometry included in the analysis was performed by two experienced observers using identical equipment which was calibrated four times daily. The three $x$ ray readers were also experienced; they used common standard and trigger films. Thus the information obtained was of good quality apart from the indices of exposure. The latter, as well as having a rather poor reproducibility, also made no allowance for the individual welders adopting different postures or positions for the exhaust ventilation hose. An attempt to improve the exposure indices by incorporating information on heat exposure-for instance, arc eye or skin burns-was unsuccessful as the latter features failed to identify heavily exposed men and no systematic personal sampling had been carried out. Nevertheless, relatively crude information of this type has been adequate to identify exposure effects in other studies.
ASPECTS OF ANALYSIS

The original survey population was enlarged by the. inclusion of foreman welders and plumber welders; the former had previously been welders and their exposure? to fume was estimated with an accuracy similar to tha? for other men. The plumber welders had a differen exposure but they constituted fewer than $6 \%$ of mer classified as welders. Nine men were aged 20 or less? hence their lungs were still growing and smaller thares predicted using the adult model relating lung function to age. Only three were exposed to fumes ( 2 welders, $L$ caulker/burner), however, so the error this introduced into the analysis was small.

The numbers of men in subgroups defined by trade and smoking category were adequate for the analyses except in the case of non-smoking other tradesmenos this group comprised only 19 men.

A difficulty with the analysis was the high correlin tion that obtained between age and many of the exposure indices, also between the interaction terms and their component variables. Principal component $\vec{z}$ regression analysis was considered as a means ot overcoming this source of error ${ }^{21}$ but rejected as the resulting factors could not be interpreted precisely. In the event error was minimised by confining the analysis to uncorrelated variables. To this end average exposure was used instead of total exposure and the constituents of interaction terms were centred about their mean values.

\section{RESPIRATORY SYMPTOMS}

Shipyard workers over the age of 50 were found tọ have significant respiratory morbidity including chronic bronchitis in $40 \%$ of men, wheeze on mose days or nights in $25 \%$, and undue breathlessness on exertion also in $25 \%$ of those in this age group. These prevalences were similar to those observed in the 1950 s by Higgins and Cochrane in coalminers and foundry. workers ${ }^{22}$ but they were higher than have been reporin ted in most other series. ${ }^{23}$ Breathlessness was the men's principal complaint. It resulted from many factors some of which, such as chronic bronchitis and pleur? isy, were themselves related to occupational fumb exposure. Omitting these and after allowing for age and stature, there was a significant association be 0 tween breathlessness and trade as a welder or caulker/ burner. The association was independent of chroniq bronchitis but was related to whether or not the men had ever smoked. Among welders and caulker/burnerse who were current smokers the likelihood of breathless ness was related to the fume exposure. The possibles reasons for the breathlessness are considered below. $\cdot$

Chronic bronchitis is traditionally associated with occupations entailing exposure to dusts and fumes; the average prevalence is usually reported as about double that in other occupations ${ }^{24}$ but less than that due too 
smoking. In the present study the relative risk of chronic bronchitis for welders and caulker/burners was 2.8 times that for other tradesmen, and comparable with that of smoking. There was significant interaction between these two effects such that the likelihood of chronic bronchitis was significantly related to the average fume exposure in the smokers but not the non-smokers or ex-smokers, either separately or in combination (table 5). Thus there was strong evidence that the fumes affected the lungs of smokers and that the large number of welders who abandoned smoking benefited by so doing. This possibility was suggested by Barhad and colleagues. ${ }^{25}$ Chronic bronchitis, together with age and smoking, were the principal factors associated with wheeze. After allowing for age and smoking, however, the occurrence of wheeze was related to the fume exposure; the association was strongest for the exsmokers which suggested that, unlike in the case of chronic bronchitis, abandoning smoking did not bring relief from the fume related component of this symptom. Wheeze was more common in men with previous metal fume fever. Experience of this condition was reported equally often by welders and caulker/burners who had ever smoked but by rather more nonsmoking welders than caulker/burners. The occurrence of metal fume fever was independent of the estimated average fume exposure but the estimate was probably influenced more by recent than previous exposure, so a real association could have been missed. Information on atopic status could have thrown light on the mechanisms. The study failed to confirm that welding fumes contributed to an increased prevalence of pneumonia, though this had been expected in the light of other evidence. ${ }^{2627}$ The prevalence of pleurisy was increased, however. This was not due to concurrent exposure to asbestos. In addition, siderosis and sensitisation arising from keeping pigeons or budgerigars appeared not to have contributed to any of the abnormalities observed.

\section{LUNG FUNCTION}

The welders and caulker/burners who had ever smoked were found to have exposure related narrowing of both large and small airways. The impairment associated with exposure was the same at all ages in the case of $\mathrm{FEV}_{1}$ and $\mathrm{PEF}$ but was greater in the older than the younger subjects for the FEV\%, maximal expiratory flow rates at small lung volumes, and the transit time indices. For all but the $\mathrm{FEV}_{1}$, where the separate results for welders and caulker/burners were not significant, similar relations with fume exposure were obtained for smokers and ex-smokers and welders and caulker/burners separately. In addition, the inclusion of non-smokers did not alter the significance of the coefficients on exposure, except marginally for
$\mathrm{FEV}_{1}(\mathrm{p}=0.053)$. Thus the evidence for welding fumes contributing to airway narrowing in smokers and ex-smokers was internally consistent. The evidence for a similar effect in non-smokers was weak but this could have been due in part to this group only comprising 73 men. Among the smokers and exsmokers, the average reductions in $\mathrm{FEV}_{1}$ and PEF associated with fume exposure were respectively 0.251 and $0.991 \mathrm{~s}^{-1}$ which were $8 \%$ and $11 \%$ of the mean values. These changes were of similar magnitude to those associated with smoking compared with nonsmoking (respectively 0.231 and $0.881 \mathrm{~s}^{-1}$ ) and sufficient to cause breathlessness on exertion in some individuals, ${ }^{28}$ especially those who also had chronic bronchitis. For the other indices, the apparent bronchoconstrictor effect of fume exposure in men who had ever smoked increased with age. This could have been due to both the cumulative effect of prolonged exposure to lung irritants and higher fume exposures in the past. Similar changes would then have been expected for the FEV ${ }_{1}$ and PEF. That these were not observed might have been due in part to confounding factors. Thus the young welders had a higher mean $\mathrm{FEV}_{1}$ than the other tradesmen and among the current non-smokers, the welders had higher levels of PEF than the caulker/burners. These changes could have been due in part to shipyard recruits of robust physique having been selected as welders and to welding possibly exerting a training effect on the accessory muscles of respiration. Selective loss from the shipyard population of men with respiratory impairment appeared not to have been a material factor in the years immediately preceding the study when the labour turnover was small. It became so subsequently, however, during a period when many men were laid off (paper in preparation) and its operation during the earlier period cannot altogether be ruled out. Full interpretation of the effect of these and other factors would require longitudinal study. Meanwhile, the present results provide internally consistent evidence for interaction between smoking and exposure to fumes as a welder or caulker/burner causing chronic bronchitis, narrowing of both large and small lung airways, and breathlessness on exertion. The physical nature of the work might itself also exert a contributory effect; on the one hand, developing the accessory muscles of respiration and, on the other, in the case of work in confined spaces leading to loss of fitness for sustained work with the legs among men who did not also engage in active leisure time activities. ${ }^{29}$ The association of chronic bronchitis and narrowing of all classes of airways with fume exposure was consistent with the findings of the other studies cited but the association was stronger than in many of them. This could have been due to shipyard welders in confined spaces having higher fume exposures than 
workers in dockyards where semi-confined spaces would have been more usual, or in factories where fixed exhaust ventilation was in use. This, however, is speculative in the absence of reliable measurements of personal fume exposure. The study provided no support for the view that occupational bronchitis was associated mainly with narrowing of large rather than small airways. ${ }^{30}$

Other factors that contributed to the result were the availability of longitudinal measurements which provided evidence on quality control and rigorous exclusion of error due to collinearity from the statistical analysis. While the effect of fume exposure was relatively large, however, its nature was similar to that observed in other studies. The adverse effect of fumes was mainly confined to smokers and ex-smokers who formed the great majority of shipyard workers. A larger number of non-smokers would have been needed to explore fully the effects of fumes in this section of the workforce. On average the effect of fumes was similar to that of being a smoker. Whereas among the welders who smoked, however, the magnitude of the effect of smoking was independent of the number of cigarettes smoked a day, the effect of fume exposure was related to the average intensity but the gradient was relatively shallow. In the case of both FEV $_{1}$ and PEF the effect of being in the upper rather than the lower $5 \%$ of the exposure range was associated with an average decrement of lung function of 1.5 times compared with 0.5 times that of smoking. In addition, the reductions with exposure in FEV\%, MEF, and transit times were larger among the older men, which suggested that the respiratory impairment reflected mainly conditions in the past; it could then have been due to there having been no exhaust ventilation. In the case of FEV, and PEF the interaction term AE $\times$ age was not significant at the $5 \%$ level, but with a p value of 0.07 it was not inconsistent with this hypothesis.

In view of these findings the present results appear to relate mainly to previous conditions in the industry. The effects of present day conditions and information on welding fumes in non-smokers must await the result of longitudinal studies on men only exposed to such conditions.

This study was made possible by the wholehearted support of the Boilermakers Union and the management and staff of Messrs Austin and Pickersgill, Sunderland. Mr T Ayre (personnel servicing manager) supervised the sampling and the shop stewards supervised the appointments; Dr V J Metcalf and Dr J H R Ramsay conducted some clinical interviews; Sister Wrought and Nursing Officer Murphy made many of the anthropometric measurements; Mrs B Wright and Dr I Ashton made the spirometric measurements; Dr P
Elmes, Dr A E Cockcroft, and Dr J Lyons read the chest radiographs; Mr R A McNay, regional statis tician, Northern Regional Health Authority, and: Dr J Whitehead, department of applied statistics University of Reading, provided statistical facilities and advice. Dr F M El-Gamal, Dr V Woolley, and M드 I C Stevenson performed some of the analyses. ELF and CACW received grants respectively from the Northern Regional Health Authority and SERG (grant number 85141933X), JEC was supported by the Medical Research Council, and VW by Health and $\vec{P}$ Safety Executive. FSR and FMEIG were in receipt of scholarships respectively from the Royal College of Physicians (Prophit) and the Committee of Unite $\$$ Kingdom Vice-Chancellors and Principals. Messrs P K Morgan donated some equipment. Professo ss P D Oldham, Dr G Berry, and Surgeon-Commandetr G H C McMillan kindly commented on an earlis version of the manuscript.

\section{References}

1 Newhouse ML, Oakes D, Woolley AJ. Mortality of welders ande other craftsmen at a shipyard in NE England. Br J Ind Me£ 1985;42:406-10.

2 Oxhoj H, Bake B, Wedel H, Wilhelmsen L. Effects of electric ar welding on ventilatory lung. Arch Environ Health 1979;34 211-7.

3 Fogh A, Frist G, Georg J. Respiratory symptoms and pulmonar function in welders. Ann Occup Hyg 1969;12:213-8.

4 Hunnicutt TN Jr, Cracovaner DJ, Myles JT. Spirometriळ measurements in welders. Arch Environ Health 1964;8:661-9.

5 Newhouse ML, Murray R. The present position concerning the biological effects of exposure to fume in welders. Abington Hall? Cambridge: Welding Institute, 1979. (Publ 5510/46/79.)

6 McMillan GHG. The health of welders in naval dockyards: the risk of asbestos-related diseases occurring in welders. $J$ Occup Med 1983;25:727-30.

7 Stern RM. Assessment of risk of lung cancer for welders. Arch Environ Health 1983;38:148-55.

8 McMillan GHG, Pethybridge RJ. The health of welders in nava $B$ dockyards: proportional mortality study of welders and twoh control groups. Journal of the Society of Occupational Medicine 1983;33:75-84.

9 Kilburn KH, Warshaw R, Boylen CT. Airway obstructiono volume loss and respiratory symptoms in shipyard welders in Los Angeles: baseline values and cross shift changes. In: Stein RM, Berlin A, Fletcher AC, Järvisalo J, eds. Health hazards and. biological effects of welding fumes and gases. Amsterdamin Elsevier, 1986:383-6.

10 McMillan GHG, Molyneux MK. The health of welders in navain dockyards: the work situation and sickness absence patterns Journal of the Society of Occupational Medicine 1981;31:43-60

11 Akbarkhanzadeh F. Long-term effects of welding fumes uporo respiratory symptoms and pulmonary function. J Occup Med 1980;22:337-41.

12 Cotes JE. Lung function: assessment and application in medicine 4th ed. Oxford: Blackwell, 1979.

13 McDermott M, McDermott TJ. Digital incremental techniqueso applied to spirometry. Proceedings of the Royal Society of Medicine 1977;70:169-71.

14 Chinn DJ, Cotes JE. Transit times analysis of spirograms: which blow is best? Bull Eur Physiopathol Respir 1986;22:461-6. 
15 International Union against Cancer Committee. UICC/Cincinnati classification of the radiographic appearances of pneumoconiosis. A comparative study by the UICC committee. Chest 1970;58:57-67.

16 Musk AW, Cotes JE, Bevan C, Campbell MJ. Relationship between type of simple coalworkers' pneumoconiosis and lung function. A nine-year follow-up study of subjects with small rounded opacities. Br J Ind Med 1981;33:313-20.

17 Medical Research Council. Definition and classification of chronic bronchitis for clinical and epidemiological purposes. Lancet 1965;i:775-9.

18 Fletcher CM. The clinical diagnosis of pulmonary emphysemaan experimental study. Proceedings of the Royal Society of Medicine 1952;45:577-8.

19 Nie NH, Hull CH, Jenkins JC, Steinbrenner K, Bent DH. Statistical package for the social sciences. 2nd ed. New York: McGraw-Hill, 1975.

20 Dixon WJ. BMDP statistical software. Los Angeles: University of California Press, 1981.

21 Darlington RB. Multiple regression in psychological research and practice. Psychol Bull 1968;69:161-82.

22 Higgins ITT, Cochrane AL. Chronic respiratory disease in a random sample of men and women in the Rhondda Fach in 1958. Br J Ind Med 1961;18:93-102.
23 Fletcher C, Peto R, Tinker C, Speizer FE. The natural history of chronic bronchitis and emphysema. An eight year study of early chronic obstructive lung disease in working men in London. Oxford: Oxford University Press, 1976.

24 Gilson JC. Occupational bronchitis? Proceedings of the Royal Society of Medicine 1970;63:857-64.

25 Barhad B, Pilat L, Teculescu D. Recent progress in the study of occupational lung diseases in Romania. $\mathrm{Br} J$ Ind Med 1975;32:164-8.

26 Mosinger M, Cherpin J, Rouger P, Luccioni R, Dantin F, Danlin B. Sur les sideroses, sideroscleroses et siderosilicoses. Archives des Maladies Professionnelles de Médecine du Travail et de Sécurité Sociale 1968;29:59-66.

27 Fawer RF, Gardner AW, Oakes D. Absences attributed to respiratory diseases in welders. Br J Ind Med 1982;39:149-52.

28 Cotes JE, Zejda J, King B. Lung function impairment as guide to exercise limitation in work-related lung disorders. Am Rev Respir Dis 1988;137:1089-93.

29 Cotes JE, El-Gamal FM. Cardio-respiratory associations with shipyard welding and burning. In: Stern RM, Berlin A, Fletcher AC, Järvisalo J, eds. Health hazards and biological effects of welding fumes and gases. Amsterdam: Elsevier, 1986:395-8.

30 Morgan WKC. Industrial bronchitis. Br J Ind Med 1978;35: 285-91.

\section{Vancouver style}

All manuscripts submitted to the $\mathrm{Br} J$ Ind Med should conform to the uniform requirements for manuscripts submitted to biomedical journals (known as the Vancouver style)

The $\mathrm{Br} J$ Ind Med, together with many other international biomedical journals, has agreed to accept articles prepared in accordance with the Vancouver style. The style (described in full in Br Med J, 24 February 1979, p 532) is intended to standardise requirements for authors.

References should be numbered consecutively in the order in which they are first mentioned in the text by Arabic numerals above the line on each occasion the reference is cited (Manson ${ }^{1}$ confirmed other reports ${ }^{2-5} \ldots$ ). In future references to papers submitted to the $B r J$ Ind Med should include: the names of all authors if there are six or less or, if there are more, the first three followed by $e t$ al; the title of journal articles or book chapters; the titles of journals abbreviated according to the style of Index Medicus; and the first and final page numbers of the article or chapter.

Examples of common forms of references are:

1 International Steering Committee of Medical Editors. Uniform requirements for manuscripts submitted to biomedical journals. Br Med J 1979;1:532-5.

2 Soter NA, Wasserman SI, Austen KF. Cold urticaria: release into the circulation of histamine and eosino-phil chemotactic factor of anaphylaxis during cold challenge. $N$ Engl $J$ Med 1976;294:687-90.

3 Weinstein L, Swartz MN. Pathogenic properties of invading micro-organisms. In: Sodeman WA Jr, Sodeman WA, eds. Pathologic physiology: mechanisms of disease. Philadelphia: W B Saunders, 1974:457-72. 